A Semmelweis Egyetem Általános Orvostudományi Kar Ortopédiai Klinika, Budapest ${ }^{1}$ és a Great Ormond

Street Hospital for Children, Orthopaedic and Spinal Surgery Unit, London ${ }^{2}$ közleménye

\title{
Komplex végtagdeformitások kezelése Taylor végtaghosszabbító készülékkel
}

\author{
DR. DOMOS GYULA ${ }^{1}$ DR. KISS SÁNDOR ${ }^{1}$, DR. TEREBESSY TAMÁS ${ }^{1}$, \\ DR. HORVÁTH NIKOLETTA ${ }^{1}$, DR. ROBERT HILL², DR. SZÖKE GYÖRGY ${ }^{1}$
}

\section{ÖSSZEFOGLALÁS}

A Taylor Spatial Frame (TSF) egy második generációs cirkuláris fixateur externe rendszer, amelynek segítségével a hosszkülönbséggel és többsíkú tengelyeltéréssel járó komplex végtagdeformitások az llizarov készüléknél egyszerűbben és pontosabban korrigálhatók. A készülék újdonsága a két gyűrűt összekötő hat teleszkópos rúd. A rudak hosszabbítását egy számítógépes program által meghatározott rend szerint végezve a tengelyeltérések, rotációs és transzlációs deformitások a callus distractio elve szerint végzett végtaghosszabbítással egy időben korrigálhatók. A szerzők Magyarországon elsőként, 2013 óta alkalmazzák a Taylor készüléket. A közleményben három különböző indikációval végzett beavatkozás, egy tumor reszekciót követően kialakult lábszárdeformitás, egy lábszárhosszabbítás során megjelent szekunder tengelyeltérés és egy poszttraumás femurdeformitás korrekciójának eredményeit ismertetik, bemutatva az eszköz és a szoftver múködését, illetve a készülék egyéb indikációs lehetőségeit.

\section{Kulcsszavak: $\quad$ Alsó végtag; Külső rögzítök; Ortopédiai készülék; Végtagdeformitás; Végtaghosszabbítós;}

Gy. Domos, S. Kiss, T. Terebessy, N. Horváth, R. Hill, Gy. Szöke: Treatment of complex limb deformities with Taylor limb lengthening device

The Taylor Spatial Frame (TSF) is a second generation circular external fixator, with it complex limb deformities with length discrepancies and multiplanar deviations can be corrected more easily and more accurately than with llizarov fixator. The novelty of the device is six telescopic struts connecting to the two rings. By adjusting the strut lengths according to a computer programme angular, rotational and translational deformities can be corrected simultaneously with limb lengthening, based on the principle of callus distraction. The authors introduced the Taylor Spatial Frame in Hungary in 2013 and applied it since then. The authors present the results of the procedures for three different indications, a tibial deformity formed after a tumor resection, a tibial elongation related secondary axis deviation and a posttraumatic femoral deformity to demonstrate the function of the frame and the software and other possible indications of the Spatial Frame.

Keywords: $\quad$ Bone lengthening - Instrumentation/methods; Equipment Design;

External fixators; Leg length inequality - Surgery;

Lower extremity deformities, congenital - Surgery;

Orthopedic procedures - Instrumentation; 


\section{BEVEZETÉS}

Ilizarov cirkuláris fixateur externe rendszere az 1980-as évek elejétől kezdődően vált nemzetközileg is ismertté (11), amellyel új fejezet nyílt a végtagdeformitások mútéti kezelésében. Az llizarov készülék nyújtotta stabilitás, a periosteumot kímélő mútéti technika, valamint a callus distractio elvének alkalmazása által jelentős végtaghossz különbségek, csontszegment hiányok, illetve egyszerúbb tengelyeltéréssel járó végtagdeformitások is eredményesen korrigálhatóvá váltak (44). A komplex, többsíkú tengelyeltéréssel járó végtagdeformitások Ilizarov készülékkel történő kezelése azonban sokszor nehézségekbe ütközik $(8,38,41)$, gyakran bonyolult felépítésű készülékek segítségével sem sikerül pontosan korrigálni ezen eseteket (18).

1994-ben az amerikai Charles Taylor mindezen nehézségek miatt módosította llizarov eszközét és kifejlesztett egy második generációs cirkuláris fixateur externe rendszert (Taylor Spatial Frame - TSF, Smith\&Nephew, USA), amely felépítésében és múködésében is alapvetően különbözik a korábbi körgyűrűs rendszertől (43). Az új készülékben a menetes rudak helyett hat teleszkópos rúd köt össze két gyúrút (1. a. ábra). Ebben az úgynevezett hexapod rendszerben a rudak hoszszának változtatása által az egyik gyürühöz képest a tér tetszőleges irányában módosíthatjuk a hozzá kapcsolódó másik gyűrű helyzetét. Ezáltal a hozzájuk kapcsolódó csontszegmentumoknak az egymáshoz viszonyított helyzete is tetszőlegesen változtatható. Így az eszköz segítségével nem csak végtaghosszabbítás végezhető, de frontális, sagittalis síkú tengelyeltérésekkel, rotációs hibákkal, valamint ad latus diszlokációval járó komplex végtagdeformitások is korrigálhatók (1. b. ábra).

A Taylor készülék használatához egy szoftver szükséges. A programmal modellezhető az adott végtagdeformitás, a felhelyezett készülék adatainak és helyzetének leírását követően pedig megtervezhető a korrekció, illetve kiszámítható a teleszkópos rudak naponként végzendő hosszabbításának rendje is. A szoftver használatával a deformitások pontosan korrigálhatók, a folyamat pedig szükség szerint újratervezhető, ezáltal egy esetleges residualis, vagy a hosszabbítás során másodlagosan kialakult tengelydeformitás is eredményesen korrigálható.

Klinikánkon 2013-ban kezdtük alkalmazni a Taylor készüléket és azóta 7 esetben használtuk a végtaghossz különbséggel és tengelyeltéssel járó congenitalis vagy poszttraumás eredetû komplex végtagdeformitások kezelésére. Közleményünkben az első három, különböző indikációval végzett korrekció eredményeit ismertetjük.

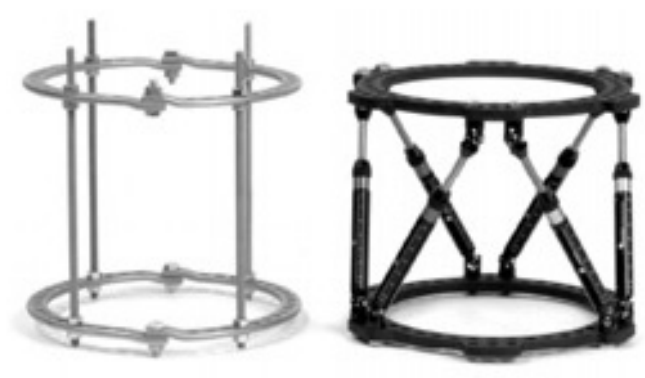

1. a. ábra

Az Ilizarov készülék és a Taylor Spatial Frame alapkonstrukciójának felépitése

(bal oldal: Ilizarov készülék, jobb oldal: TSF)

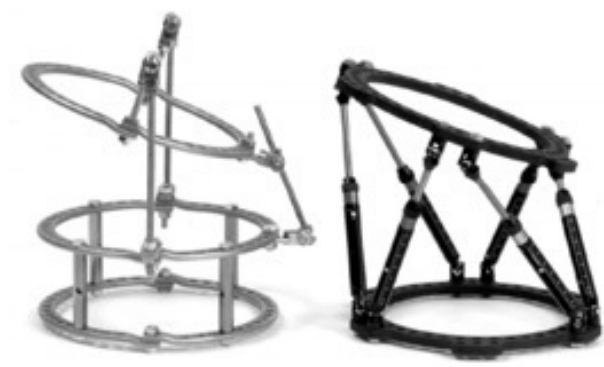

1. b. ábra

Példa a két gyürü egymáshoz viszonyított helyzetének változtatására a két rendszerben (frontalis síkú tengelyeltérés) Forrás: www.jcharlestaylor.com 


\section{ESETISMERTETÉSEK}

A Taylor készülékkel történő végtaghoszszabbítást minden esetben az llizarov készüléknél is alkalmazott callotasis elv szerint végeztük (a posztoperatív 7-10. naptól, napi $1 \mathrm{~mm}$-es sebességgel végzett callus distractio). $\mathrm{Az}$ osteotomia végzésének módja, a gyűrűk rögzítésének általános alapelvei, illetve az utókezelés protokollja (teljes terhelés és intenzív gyógytorna a 2. posztoperatív naptól kezdődően, kéthetente végzett radiológiai kontroll, nyársak körüli bőrápolás) nem különbözött az Ilizarov készülékkel történő hosszabbítás protokolljától. A készülék eltávolítását akkor végeztük, amikor az AP és oldalirányú röntgenfelvételeken a callus területén képződő négy corticalis csont közül legalább három kialakulását észleltük. A kezelés időtartamát a gyógyulási index (gyógyulási idő/hosszabított cm) alapján értékeltük.

\section{1. eset}

Egy 13 éves fiúnál 5 éves korában a jobb tibia proximalis metaphysisének Ewing sarcomája miatt végtagmegtartó mútétet: a tibia proximalis epiphysisének megtartásával járó szegment reszekciót, autológ (ellenoldali) fibula transzpozíciót, az operált oldali fibula diaphysealis osteotomiáját és a tibiacsonkokhoz történő rögzítését (fibula pro tibia), kiterjedt lágyrészreszekciót és Ilizarov készülékes rögzítést végeztünk. Az átültetett fibula elhúzódó beépülése miatt a térdízületet áthidaló Ilizarov készüléket két évvel a mútétet követően távolítottuk el. A gyermek alapbetegségének gyógyulását követően a növekedés során a tibia proximalis physisének reszekciója és a femur distalis növekedési porcának károsodása miatt a femurt és a lábszárat egyaránt érintő rövidülés alakult ki. A gyermek 10 éves korában a végtagrövidülés mértéke $6 \mathrm{~cm}$ volt, amely miatt az ellenoldali alsó végtag növekedésgátlását, a tibia proximalis végének nyolcas lemezes epiphyseodesisét (21) végeztük, majd 12 évesen a már $10 \mathrm{~cm}$-es végtagrövidülés miatt $4 \mathrm{~cm}$-es Ilizarov készülékes lábszárhoszszabbítást, illetve a boka valgus deformitása miatt csavaros belboka epiphyseodesist végeztünk. 13 éves korában a végtaghossz különbség mértéke $8,3 \mathrm{~cm}$ volt, amelyben elsősorban a femur növekedésének elmaradása játszott szerepet: 1,9 cm-es lábszár és 6,4 cm-es femurhossz különbség alakult ki.

$A z$ operált tibián az átültetett fibula proximalis és distalis csatlakozási pontjánál, illetve az Ilizarov készülékkel történt diaphysealis hosszabbítás területén többszintű, komplex tengelydeformitás alakult ki. A diaphysisen a röntgenfelvételeken öszszességében 21 fokos valgus irányú, 10 fokos recurvatiós és klinikailag 10 fokos kirotációs deformitást né:tünk, emeliett -- à tibia diaphysis proximalis részéhez képest - 13 fokos ventralis irányú tibia plató lejtést és a proximalis tibio-fibularis csatlakozás szintjében 8 fokos varus tengelyeltérést észleltünk (2. a ábra). A gyermek a végtaghossz különbség és a részleges izomhiány, illetve a lábszár komplex deformitása miatt csak $8 \mathrm{~cm}$-es emeléssel készült járógépben volt járóképes.

A deformitás komplexitására tekintettel Taylor készülékkel végeztük a lábszár hoszszabbítását és a tibia diaphysis tengelyeltérésének korrekcióját. A mútét során az ellenoldali femur növekedésgátlása céljából distalisan nyolcas lemezes epiphyseodesist, majd a jobb belboka epiphseodesise miatt korábban behelyezett csavar eltávolítását végeztük. Ezt követően a jobb tibia diaphysealis tengelyeltérésének középpontjában osteotomiát végeztünk és felhelyeztük a Taylor készüléket. A készülék két gyűrűjét 2-2 keresztezett Kirschner dróttal és egy-egy Schanz csavarral rögzítettük a tibiához, amely megfelelő stabilitást nyújtott, kiegészítő gyűrűkre nem volt szükség.

A műtétet követően a szoftver segítségével megterveztük a korrekciót. Elsőként leírtuk a deformitás paramétereit mindhárom síkban (3. a ábra), majd megadtuk a felhelyezett készülék adatait, és meghatároztuk a referenciagyűrünek a csonthoz viszonyított elhelyezkedését. Ezen adatok alapján a szoftver kiszámította és modellezte a kezdeti, illetve a hosszabbítás és tengelykorrekció után elérni kívánt helyzetet, mind a frontalis, mind pedig a sagittalis és transversalis síkokban (3. b ábra). A hosszabbítás sebességének (1 $\mathrm{mm} /$ nap) megadását követően a program kiszámította az elongatio egyes lépéseit is. A teleszkópos rudak naponta szükséges állításának adatait táblázat formájában kinyomtatva adtuk a gyermeknek, aki a hosszabbítást a közös kezdeti lépéseket követően otthonában önállóan, szülői felügyelet mellett végezte. 
A tengelykorrekcióval szimultán végzett végtaghosszabbítást a callotasis elve alapján, a posztoperatív 7. napon kezdtük el. A program által meghatározott rend szerint végzett elongatio során mérsékelt fokú flexiós térdkontraktúra alakult ki, amely a későbbiekben a készülék eltávolítását követően néhány hét alatt megszűnt, egyéb szövődmény nem alakult ki, a tervezett korrekciót elértük. A hosszabbítás során $4 \mathrm{~cm}$-es rövidülést, 21 fokos valgus irányú, illetve 10 fokos
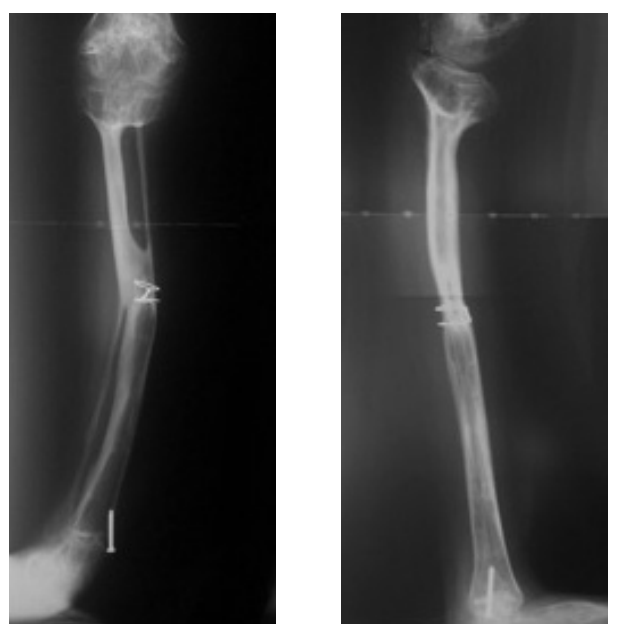

\section{2. a. ábra}

A preoperativ röntgenfelvételeken 21 fokos diaphysealis valgus és 10 fokos recurvatio észlelhetö (analóg röntgenfelvételek, bal oldal: AP felvétel, jobb oldal: oldalfelvétel)

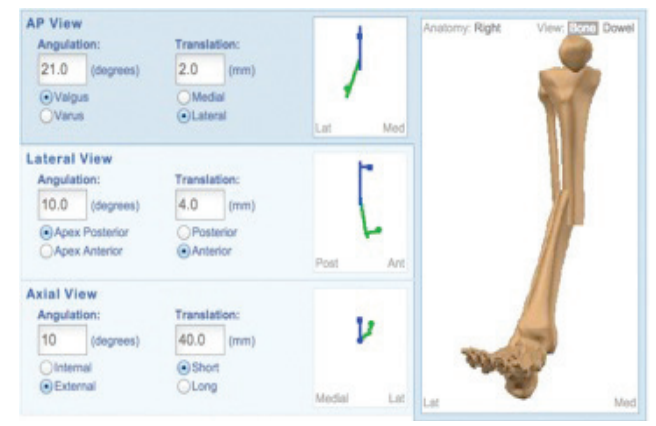

3. a. ábra

A deformitás paramétereinek leírása és modellezése mindhárom síkban a szoftver segítségével recurvatiós, valamint 10 fokos kirotációs deformitást korrigáltunk (2. b ábra). A készüléket a callus megfelelő csontosodását követően, 6 hónappal a mútét után eltávolítottuk, a gyógyulási index 46,5 nap/cm volt. A gyermeknél jelenleg még 4,3 cm-es végtagrövidülés és a proximalis tibio-fibularis csatlakozás szintjében lévő deformitás miatt mérsékelt genu varum észlelhető, amely miatt következő lépésben a femur hosszabijítását és a még megị̂vô ten!.. gelyeltérés korrekcióját tervezzük.
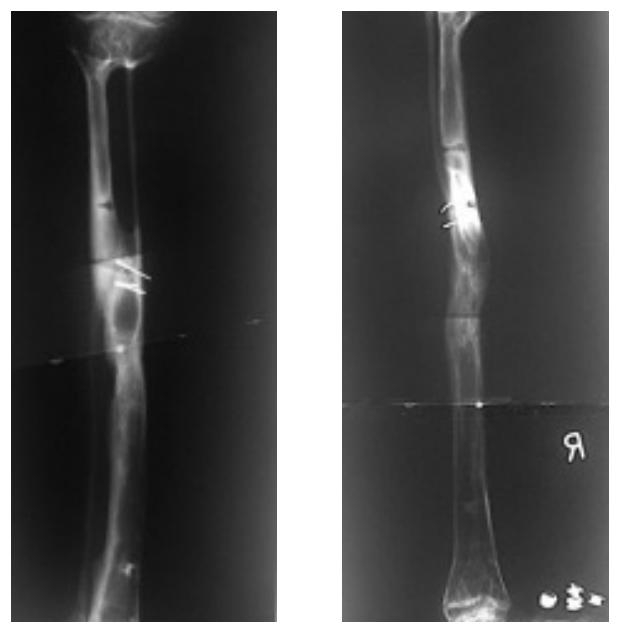

2. b. ábra

A 4 cm-es hosszabbitást követő röntgenfelvételeken a diaphysealis tengelydeformitások gyakorlatilag megszüntek (analóg röntgenfelvételek, bal oldal: AP felvétel, jobb oldal: oldalfelvétel)

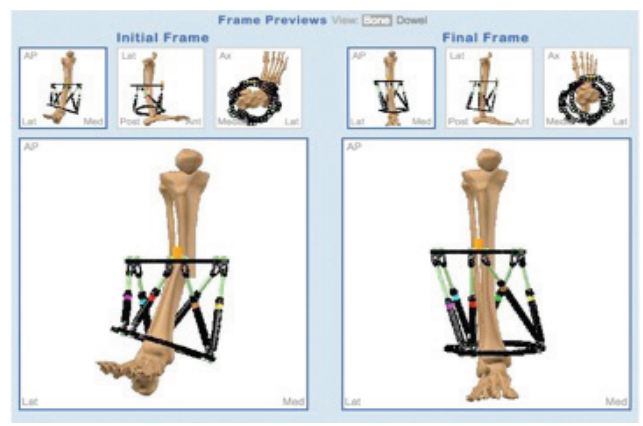

\section{3. b. ábra}

A szimultán végzett végtaghosszabbitás és tengelykorrekció modellezése a szoftver segítségével a különböző síkokban (bal oldal: hosszabbitás elött, jobb oldal: hosszabbítás után) 


\section{2. eset}

Egy 8 éves, bal oldali fibula hemimelia miatt gondozott fiúnál $4 \mathrm{~cm}$-es, tengelyeltéréssel nem járó lábszárrövidülés miatt végeztünk végtaghosszabbítást Taylor készülékkel. A tibia proximalis metaphysis területén végzett osteotomiát követően a készülék proximalis és distalis gyűrűjét 2-2 keresztezett Kirschner dróttal és egy-egy Schanz csavarral rögzítettük a tibiához. A mútétet követő első hét elteltével napi $1 \mathrm{~mm}$-es sebességgel, mind a 6 teleszkópos rudat azonos mértékben hosszabbítva végeztünk elongatiót.

A hosszabbítás befejezésekor készült röntgenfelvételeken 8 fokos valgus irányú és 8 fokos antecurvatiós tengelyeltérést észleltünk (4. a ábra), amely klinikailag is szembetűnő deformitást okozott. A készüléket ellenőrizve a teleszkópos rudak azonos állásban voltak, a szülők a hosszabbítást a terv szerinti ütemben, pontosan végezték.
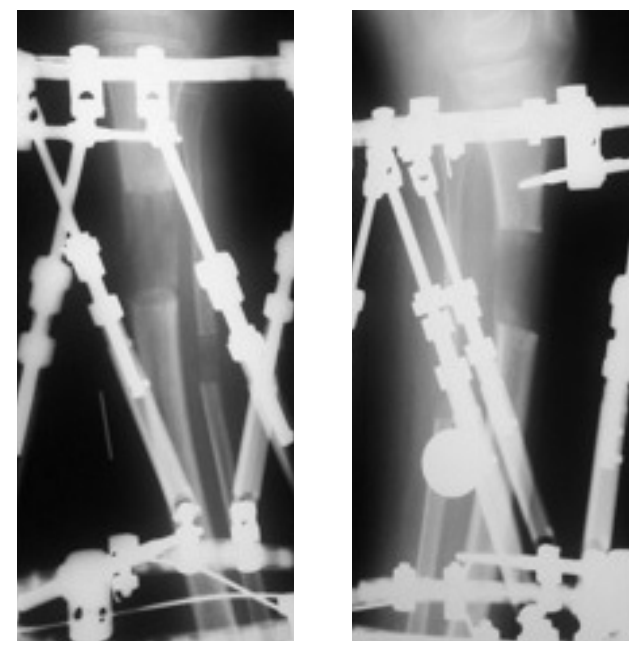

4. a. ábra

A hosszabbitást követöen 9 fok valgus és 7 fok antecurvatio alakult $k i$

(analóg röntgenfelvételek, bal oldal: AP felvétel, jobb oldal: oldalfelvétel)
Az elongatio során ezen kívül mérsékelt fokú Achilles contractura is kialakult (a láb plantigrad helyzetig volt dorsalflectálható), amely a későbbiekben a készülék eltávolítását követően néhány hét alatt megszúnt, egyéb szövődmény nem alakult ki.

A hosszabbítás ideje alatt, másodlagosan kialakult tengelyeltéréseket a szoftver segítségével korrigáltuk. A program a kialakult deformitás paramétereinek, ilictve a felinelyezect készülék adatainak megadását és a tibiához viszonyított helyzetének meghatározását követően modellezte a kiindulási és a tervezett korrekció utáni állapotot és kiszámította a korrekció lépéseit. A sagittalis és frontalis síkú tengelydeformitásokat a szoftver által meghatározott módon, 7 nap alatt teljes mértékben korrigáltuk (4. b. ábra). A készüléket a mútét után 4 hónappal, a callus megfelelő ossificatióját követően távolítottuk el, a gyógyulási index 29 nap/cm volt.
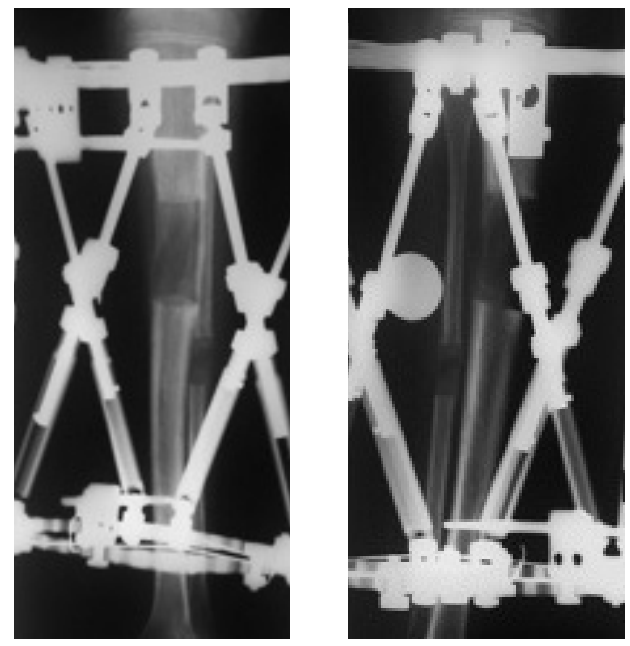

\section{4. b. ábra}

A tengelykorrekciót követöen a deformitás megszünt, az AP felvételen jól kivehető az aszimmetrikus callus (analóg röntgenfelvételek, bal oldal: AP felvétel, jobb oldal: oldalfelvétel) 


\section{3. eset}

Egy 16 éves fiú 10 éves korában történt motorbaleset kapcsán bal oldali distalis femur epiphyseolysist szenvedett, amelyet primeren csavaros osteosynthesissel stabilizáltak. A sérülés miatt a femur distalis pyhysisének medialis fele lezáródott, és a növekedés során jelentős varus deformitás és femur rövidülés alakult ki. A gyermek 12 éves korában a deformitás $2 \mathrm{~cm}$-es végtagrövidüléssel és 20 fokos genu varummal járt, amely miatt a femur distalis végén lateralisan nyolcas lemezes epiphyseodesist végeztünk (39). 13 éves korában korrekciós supracondylaer femur osteotomiát, illetve az ellenoldali alsó végtag növekedésének gátlása céljából az ellenoldali femur distalis és a tibia proximalis végének medialis és lateralis oldalán nyolcas lemezes epiphyseodesist is végeztünk (21).

A további növekedés során a varus deformitás ismételten megjelent, progrediált és a gyermek 16 éves korára 35 fokos varus deformitás és az antecurvatio 10 fokos fokozódása alakult ki (5. a ábra). Az ellenoldali alsó végtag epiphyseodesise a növekedés ütemét csökkentette (a jobb tibia $7 \mathrm{~mm}$-rel volt rövidebb a bal tibiánál), azonban mindezek ellenére az alsó végtagi hosszkülönbség 4,3 cm-es mértékig fokozódott (a femur rövidülésének mértéke $5 \mathrm{~cm}$ volt). Ezen kívül, a nagyfokú genu varum kompenzációjaként a bal lábszáron 8 fokos valgus deformitás is kialakult.

A fiatalembernél a növekedés befejeződését követően Taylor készülékkel végeztük a deformitás korrekcióját. A tervezett mútéti sorozat helyett (a femurdeformitás teljes korrekciója Taylor készülékkel, majd második lépésben a tibia kompenzációs valgus deformitásának korrekciója) tekintettel a korábbi 13 mútétre és az ezekkel járó megpróbáltatásokra a szülők és a gyermek kérése alapján egylépcsős korrekciót végeztünk a femur deformitásának subtotalis korrekciójával. Így a hosszabbítás befejezésekor a femur mérsékelt varus tengelye a tibia mérsékelt kompenzációs valgus tengelyét kiegyenlítve fiziológiás alsó végtagi tengelyállást eredményezett (5. b ábra).

A mútét során a femur distalis végére felhelyeztük a Taylor készüléket (proximalisan a femur medialis felszínét szabadon hagyó 2/3-os gyúrúvel), amelyet distalisan 1 Kirschner dróttal és 2 Schanz csavarral rögzítettünk, míg proximalisan 3 Schanz csavarral fixáltunk. A posztoperatív mobilizáció időszakában a fiatalenber enyine szubjektíi insta. bilitás érzése miatt a distalis gyűrüt 1 további Schanz csavarral fixáltuk, amelyet követően a 90 kg-os beteg korábbi panaszai megszűntek.

A mútétet követően a szoftver segítségével megterveztük a korrekciót. A nagyfokú tengelyeltérésre, és a femur medialis oldalán a lágyrészek várhatóan jelentős feszülésére tekintettel a deformitás korrekcióját több lépésben végeztük. A posztoperatív 10. napon kezdett korrekció során elsőként 2,5 cm-es hosszabbítást és 32 fokos varus korrekciót terveztünk meg. A hosszabbítást követően, de még a tengelykorrekció befejezése előtt $5 \mathrm{~mm}$-es lateralis és $5 \mathrm{~mm}$-es dorsalis irányú ad latus diszlokációt észleltünk. A programot újraterveztük, és az ad latus diszlokációk korrekciója mellett 2 lépésben további $1,5 \mathrm{~cm}$-es hosszabbítást végeztünk, illetve emellett 7 fokos antecurvatiós eltérést is korrigáltunk. Ennek során medialisan jelentős lágyrészfeszülés, jelentős, de nem fixált extenziós térdkontraktúra és a distalis gyűrüt rögzítő medialis Schanz csavarok körül mérsékelt felületes infekció alakult ki, amely per os antibiotikum kezelés mellett megszűnt.

Az elongatio során összességében $4 \mathrm{~cm}$-es rövidülést, 32 fokos varus irányú és 7 fokos antecurvatiós eltérést korrigáltunk, emellett a mútét és a hosszabbítás során kialakult néhány mm-es nagyságrendű ad latus diszlokációkat is korrigáltuk (5. $b$ ábra). A készüléket a mútét után 9 hónappal, a callus megfelelő csontosodását követően távolítottuk el, a gyógyulási index 70 nap/cm volt. A rehabilitáció során az extenziós térdkontraktúra megszűnt. 

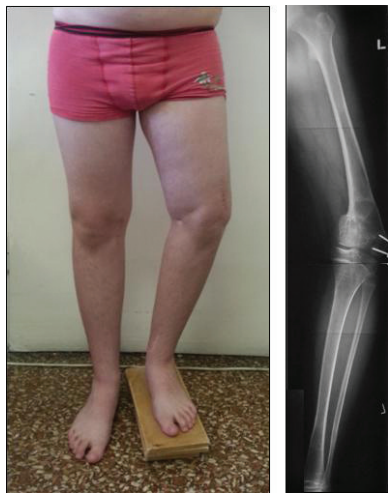

5. a. ábra

Preoperativ klinikai és radiológiai AP kép (bal oldalon 4,3 cm-es alsó végtagi rövidülés, 35 fok varus deformitás)

\section{MEGBESZÉLÉS}

A Taylor készülék 20 évvel ezelőtti bevezetése óta a gyermek- és felnőttkori végtagdeformitások kezelésével foglalkozó ortopédsebészek fontos és népszerű eszközévé vált világszerte. A múszaki életben használatos, Stewart platformnak nevezett rendszer (Id. repülőgép szimulátorok mozgatószerkezete) elvén múködő készülék segítségével a háromdimenziós végtagdeformitások korrekciója az Ilizarov készülékkel ellentétben nem egy valódi, hanem egy virtuális forgáspont körül végezhető, amely szükségtelenné teszi bonyolult felépítésű, csuklókkal kiegészített fixateur-ök kialakítását (41). A felépítésben további egyszerűséget, és a beteg számára könnyebbséget jelent, hogy az Ilizarov készülékkel szemben alapesetben nem 4, hanem csak 2 gyürü felhelyezése szükséges, amit azonban szükség esetén (például nagyobb testsúly, kétoldali szimultán mútét) kiegészíthetünk további stabilizáló gyűrűkkel. Ezen kívül, a Taylor készülékkel - több gyűrű egymáshoz kapcsolásával és több szinten végzett osteotomiával - a többszintű deformitások korrekciója egy ülésben is elvégezhető (42).

A Taylor Spatial Frame rögzítéséhez az Ilizarov készüléknél alkalmazott keresztezett Kirschner drótos fixáció mellett gyakran használnak Schanz csavaros rögzítést is, amely merevebbé, az axiális és rotációs erőkkel szemben ellenállóbbá teszi a készülékeket $(14,43)$.

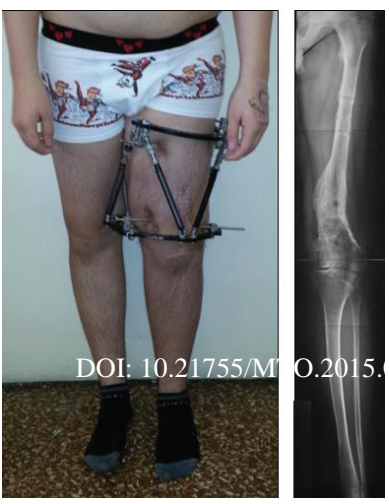

5. b. ábra

A hosszabbitást és tengelykorrekciót követő klinikai és radiológiai AP kép

(bal oldalon $4 \mathrm{~cm}$-es hosszabbitás és 32 fokos varus korrekció)

Emellett ugyanakkor biztosítja a csontgyógyuláshoz szükséges axiális mikromozgásokat is (14), és az llizarov készülékhez hasonlóan megengedi a végtag korai terhelését (24). Eseteinkben a mútétet követő 2 . napon engedtük meg az operált alsó végtagok teljes terhelését.

Egy-egy gyűrű rögzítéséhez legalább 3 K-drót vagy Schanz csavar szükséges, amelyeket részben a gyűrü proximalis, részben pedig a distalis oldala felől kell behelyezni. A készülék felépítésekor minimálisan egy $\mathrm{K}$-drót használata szükséges a megfelelő rotációs stabilitás biztosítása érdekében. Eseteink közül a lábszárhosszabbításoknál a készülék gyúrűit egy-egy keresztezett Kirschner drótpárral és egy-egy Schanz csavarral rögzítettük, amely megfelelő stabilitást biztosított. A femur korrekciója során a proximalis gyürüt 3 Schanz csavarral, a distalis gyűrüt egy $\mathrm{K}$-dróttal és 2 Schanz csavarral fixáltuk. Utóbbi azonban a túlsúlyos fiatalember esetében nem bizonyult kellően stabilnak, ezért a mútétet követően egy 3. csavar beültetésére is szükség volt a distalis gyürü stabilizálásához.

$\mathrm{Az}$ osteotomia végzésének módja, illetve a callotasis elve szerint végzett hosszabbítás (a posztoperatív 7-10. naptól, napi $1 \mathrm{~mm}$-es sebességgel végzett callus distractio) nem különböznek az Ilizarov készüléknél használt elvektől $(20,26)$. Ugyanakkor az eszköz működése alapvetően eltér az llizarov készülékétől, a virtuális csuklónak és a szoftver használatának köszönhetően a több síkú tengelyeltérések, 
rotációs hibák és ad latus diszlokációk korrekciója egyszerre is elvégezhető. Emellett pedig előre pontosan megtervezhető, és relatív egyszerűen, a gyúrúket összekötő rudak hoszszának változtatása által kivitelezhető - ellentétben a komplex deformitások llizarov készülékkel történő korrekciója során tapasztalt nehézségekkel, amely során gyakran van szükség az egyik síkban végzett tengelykorrekciót követően a készülék átépítésére a következő síkban történő tengelykorrekció elvégzéséhez $(8,38$, 41).

Mindezen tulajdonságoknak köszönhetően ráadásul nem csak egyszerúbbé, de sokkal pontosabbá, és megbízhatóbbá is válik a beavatkozás (28). A készülék pontossága kísérletes körülmények között 2 fokos a rotáció, 0,5 mm-es a hosszabbítás (37), illetve 0,7 fokos a tengelyeltérés és 1-2 mm-es az ad latus diszlokációk tekintetében (43). A Taylor készülék klinikai alkalmazása során elérhető pontosság az Ilizarov készülékkel történő korrekció pontosságát jelentősen meghaladja: Manner és munkatársai - 208 eseten (79 Ilizarov, 129 TSF) végzett retrospektív analízise szerint - a komplex deformitások tervezett korrekcióját a Taylor készülék alkalmazásakor az esetek 90,7\%-ában, míg llizarov készülékkel csak az esetek 55,7\%-ában érték el. Ez a különbség a deformitás komplexitását figyelembe véve még szembetűnőbb: egydimenziós eltérés esetén a pontosság: TSF 100\%, Ilizarov 79,3\%, kétdimenziós eltérés esetén: TSF $91,8 \%$, llizarov $48,6 \%$, háromdimenziós eltérés esetén: TSF 91,1\%, Ilizarov 28,6\%, négydimenziós eltérés esetén: TSF $66,7 \%$, Ilizarov $0 \%$ volt (18).

A Taylor készülék pontosságát és megbízhatóságát fokozza, hogy a korrekció az elongatio folyamán bármikor módosítható és újratervezhető. A végtaghosszabbítás során főként az izomzat alkalmazkodási képességének elégtelensége $(35,36)$, a lágyrészek feszülése miatt gyakori a másodlagos tengelyeltérések, illetve ad latus diszlokációk kialakulása. Eseteinkben a hosszabbítás ideje alatt a callusképződést és a csontvégek helyzetét kéthetente végzett röntgenfelvételekkel ellenőriztük, a másodlagosan kialakult tengelyeltéréseket és ad latus diszlokációkat a program újratervezésével, a készülék adott konstrukciójának módosítása nélkül korrigáltuk. A hosszabbítás során a callusképződés eseteinkben megfelelő volt, a program módosítására a callusképződés elégtelensége miatt nem volt szükség.

A program újratervezhetősége lehetőséget ad továbbá arra is, hogy a folyamat során a hosszabbítás sebességét kontrolláltan csökkentsük abban az esetben, ha a perifériás idegek feszülése miatt szenzoros vagy motoros innervációs zava: aijakuina ki. Eseíteinkben a végtagok perifériás beidegzése és keringése zavartalan volt, ezen okok miatt a program módosítására nem volt szükség.

A szoftver segítségével mindezeken kívül lehetőség nyílik arra is, hogy a végtaghosszabbítás és a tengelykorrekció szimultán, vagy akár több lépésben is elvégezhető legyen. Eseteink közül a femur poszttraumás eltérésének korrekciója során végeztünk többlépéses módszert, amellyel a tengelyeltéréseket a tervezett végtaghosszabbítás 75\%-ának elérésekor már korrigáltuk, így biztosítva a deformitás korrekcióját arra az esetre is, ha - a 30 fok feletti varus korrekciója során a femur medialis oldalán lévő lágyrészek feszülése miatt - a tervezett mértékű hosszabbítást nem tudtuk volna elérni, és idő előtt kényszerültünk volna a hosszabbítás befejezésére.

A Taylor készülék elsődleges indikációja a végtaghossz különbséggel és tengelyeltérésekkel járó komplex deformitások korrekciója, ezen esetekben az Ilizarov készüléknél egyszerúbben, pontosabban és biztonságosabban végezhető az eljárás $(5,18)$. Az egyszerű, tengelyeltérések nélküli lábszárrövidülések esetében a Taylor készülékkel történő végtaghoszszabbítás során a készüléket rögzítő Shanz csavarok aszimmetrikus elhelyezkedése miatt, a lágyrészek feszülésének következtében gyakran alakulnak ki másodlagos tengelyeltérések (elsősorban valgus és antecurvatio) (45), amelyek a program használatával eredményesen korrigálhatók, mint azt saját, 2. esetünkben is tapasztaltuk. A kialakuló tengelyeltérések miatt egyes szerzők egyszerű végtaghosszabbítás esetén elsőként választandó eljárásként az llizarov készülék alkalmazását javasolják $(5,12)$. Alternatív megoldásként a Taylor készülék gyűrűiből és az Ilizarov készülék menetes rudazataiból felépülő hibrid készülék is felhelyezhető, majd amennyiben a hoszszabbítás során tengelyeltérés vagy ad latus 
diszlokáció alakul ki, az elongatio befejezésekor a menetes rudakat a Taylor készülék teleszkópos rúdjaira cserélve, a szoftver segítségével korrigálják a másodlagosan kialakuló tengelyeltéréseket (12).

A Taylor készüléket széleskörűen alkalmazzák gyermek-, serdülő- és felnőttkori traumás esetekben, nyílt törések $(30,33,40)$, intraarticularis (1) és diaphysealis törések $(2,6)$, valamint polytraumatizált betegek (31) ellátásában is - kihasználva a Taylor készülék azon előnyét, amellyel lehetőség nyílik a deformitás posztoperatív korrekciójára is (40). Ezen kívül a törésgyógyulás zavaraiban, hypertrophiás (25) és szeptikus álízületek (27) ellátásában, elhanyagolt törések és ficamok $(13,34)$ kezelésében, illetve a szegment vándoroltatás módszerével csontdefektusok pótlására $(29,32)$ is eredményesen alkalmazzák.

$\mathrm{Az}$ eszköz további indikációja a hosszkülönbség nélküli, de tengelyeltéréssel járó végtagdeformitások (4), többek között $M$. Blount $(9,17)$, csontanyagcsere zavarok $(22)$ vagy csontrendszer betegségek (42) következtében fellépő tengelyeltérések kezelése. Különleges indikációt jelent az intraoperatív tengelykorrekció végzése az úgynevezett CHAOS módszer szerint (23), amely során a deformitást a felhelyezett Taylor készülékkel a mútét közben anatómiai pontossággal korrigálják, majd az osteotomiát rögzítő velőűrszeg vagy lemez behelyezését követően a fixateur externe-t eltávolítják.

Az eszköz alkalmazási területe nem csak indikációs szempontból széles, de gyakorlatilag minden végtagrész deformitása esetén használható, megfelelő méretű gyűrük és rudazat alkalmazásával. Az eseteinkben is szereplő femur és tibiadeformitások mellett alkalmazható a humerus (3), az alkar $(3,16)$, illetve a láb területén kialakuló congenitalis és szekunder deformitások kezelésére is $(7,10)$.

Az elmúlt évtizedben számos összehasonlító közlemény született az Ilizarov és a Taylor készülékkel végzett kezelések eredményességéről $(5,15,18,19,40)$. Ezen tanulmányok igazolták, hogy a Taylor készülék alkalmazásával az Ilizarov készülékhez hasonló eredménynyel biztosítható a csontgyógyulás inind a tö. rések rögzítése, mind pedig a végtaghosszabbítás és tengelykorrekció során végzett callus distractio esetében, a gyógyulási index, illetve a szövődmények tekintetében pedig nem találtak szignifikáns különbséget a két készülék eredményei között $(5,15,18,19,40)$. Ugyanakkor a Taylor Spatial Frame segítségével a veleszületett és szerzett komplex deformitások az Ilizarov készüléknél egyszerübben, pontosabban és megbízhatóbban korrigálhatók, amely hozzájárult az eszköz gyors elterjedéséhez és nemzetközi sikeréhez.

\section{Köszönetnyilvánítás}

A Taylor végtaghosszabbító készülékek használatára és magyarországi bevezetésére Mr. Robert Hill (Great Ormond Street Hospital, London) nagy értékű eszközadományának, illetve kitartó szakmai támogatásának köszönhetően nyílt lehetőségünk. Köszönet illeti továbbá a Smith\&Nephew céget, amely az eszköz használatához szükséges képzést és szoftvert biztosította, illetve a Magyar Ortopéd Társaságot, amely az EFORT Visiting Fellowship által lehetőséget biztosított a módszer megismerésére és a külföldi munkakapcsolat kialakítására. 


\section{IRODALOM}

1. Ahearn N., Oppy A., Halliday R., Rowett-Harris J., Morris S. A., Chesser T. J., Livingstone J. A.: The outcome following fixation of bicondylar tibial plateau fractures. Bone Joint J. 2014. 96-B. (7): 956-962.

2. Al-Sayyad M. J.: Taylor Spatial Frame in the treatment of pediatric and adolescent tibial shaft fractures. J. Pediatr. Orthop. 2006. 26. (2): 164-170.

3. Al-Sayyad M. J.: Taylor spatial frame in the treatment of upper extremity conditions. J. Pediatr. Orthop. 2012. 32. (2): 169178.

4. Ashfaq K., Fragomen A. T., Nguyen J. T., Rozbruch S. R.: Correction of proximal tibia varus with external fixation. J. Knee Surg. 2012. 25. (5): 375-384.

5. Dammerer D., Kirschbichler K., Donnan L., Kaufmann G., Krismer M., Biedermann R.: Clinical value of the Taylor Spatial Frame: a comparison with the llizarov and Orthofix fixators. J. Child Orthop. 2011. 5. (15): 343-343.

6. Eidelman M., Katzman A.: Treatment of complex tibial fractures in children with the Taylor Spatial Frame. Orthopedics, 2008. 31. (10). pii: orthosupersite.com/view.asp?rlD=31513.

7. Eidelman M., Katzman A.: Treatment of complex foot deformities in children with the Taylor Spatial Frame. Orthopedics, 2008. 31. (10). pii: orthosupersite.com/view.asp?rlD=31514.

8. Fadel M., Hosny G.: The Taylor spatial frame for deformity correction in the lower limbs. Int. Orthop. 2005. 29. (2): 125-129.

9. Feldman D. S., Madan S. S., Ruchelsman D. E., Sala D. A., Lehman W. B.: Accuracy of correction of tibia vara: Acute versus gradual correction. J. Pediatr. Orthop. 2006. 26: 794-798.

10. Ganger R., Radler C., Handlbauer A., Grill F.: External fixation in clubfoot treatment - a review of the literature. J. Pediatr. Orthop. B. 2012. 21. (1): 52-58.

11. Hasler C.C., Krieg A. H.: Current concepts of leg lengthening. J. Child Orthop. 2012. 6. (2): 89-104.

12. lobst C.: Limb lengthening combined with deformity correction in children with the Taylor Spatial Frame. J. Pediatr. Orthop. B. 2010. 19. (6): 529-534.

13. Khamaisy S., Haleem A. M., Williams R. J., Rozbruch S. R.: Neglected rotatory knee dislocation: A case report. Knee. 2014. 21. (5): $975-978$.

14. Khurana A., Byrne C., Evans S., Tanaka H., Haraharan K.: Comparison of transverse wires and half pins in Taylor Spatial Frame: a biomechanical study. J. Orthop. Surg. Res. 2010. 27. (5): 23.

15. Kristiansen L. P., Steen H., Reikerås O.: No difference in tibial lengthening index by use of Taylor spatial frame or llizarov external fixator. Acta Orthop. 2006. 77. (5): 772-777.

16. Launay F., Glard Y., Jacopin S., Jouve J. L., Bollini G.: Progressive correction of the hand in the congenital radial clubhand. Chir. Main. 2008. 27. Suppl. 1: S211-214.

17. Li Y., Spencer S. A., Hedequist D.: Proximal tibial osteotomy and Taylor Spatial Frame application for correction of tibia vara in morbidly obese adolescents. J. Pediatr. Orthop. 2013. 33. (3): 276-281.

18. Manner H. M., Huebl M., Radler C., Ganger R., Petje G., Grill F.: Accuracy of complex lower-limb deformity correction with external fixation: a comparison of the Taylor Spatial Frame with the llizarov ring fixator. J. Child Orthop. 2007. 1. (1): 55-61.

19. Menakaya C. U., Rigby A. S., Hadland Y., Barron E., Sharma H.: Fracture healing following high energy tibial trauma: Ilizarov versus Taylor Spatial Frame. Ann. R. Coll. Surg. Engl. 2014. 96. (2): 106-110.

20. Paley D.: Principles of deformity correction. Berlin, Springer, 2002.

21. Pendleton A. M., Stevens P. M., Hung M.: Guided growth for the treatment of moderate leg-length discrepancy. Orthopedics. 2013. 36. (5): e575-580.

22. Petje G., Meizer R., Radler C., Aigner N., Grill F.: Deformity correction in children with hereditary hypophosphatemic rickets. Clin. Orthop. Relat. Res. 2008. 466. (12): 3078-3085.

23. Rogers M. J., McFadyen I., Livingstone J. A., Monsell F., Jackson M., Atkins R. M.: Computer hexapod assisted orthopaedic surgery (CHAOS) in the correction of long bone fracture and deformity. J. Orthop. Trauma. 2007. 21. (5): $337-342$.

24. Rozbruch S. R., Fragomen A. T., Ilizarov S.: Correction of tibial deformity with use of the llizarov-Taylor spatial frame. J. Bone Joint Surg. Am. 2006. 88. Suppl. 4: 156-174.

25. Rozbruch S. R., Helfet D. L., Blyakher A.: Distraction of hypertrophic nonunion of tibia with deformity using Ilizarov/Taylor Spatial Frame. Report of two cases. Arch Orthop Trauma Surg. 2002. 122. (5): 295-298.

26. Rozbruch S. R., Ilizarov S.: Limb lengthening and reconstruction surgery. New York, Informa, 2007.

27. Rozbruch S. R., Pugsley J. S., Fragomen A. T., Ilizarov S.: Repair of tibial nonunions and bone defects with the Taylor Spatial Frame. J. Orthop. Trauma. 2008. 22. (2): 88-95.

28. Rozbruch S. R., Segal K., Ilizarov S., Fragomen A. T., Ilizarov G.: Does the Taylor Spatial Frame accurately correct tibial deformities? Clin. Orthop. Relat. Res. 2010. 468. (5): 1352-1361.

29. Rozbruch S. R., Weitzman A. M., Tracey Watson J., Freudigman P., Katz H. V., Ilizarov S.: Simultaneous treatment of tibial bone and soft-tissue defects with the llizarov method. J. Orthop. Trauma. 2006. 20. (3): 197-205.

30. Sala F., Capitani D., Castelli F., La Maida G. A., Lovisetti G., Singh S.: Alternative fixation method for open femoral fractures from a damage control orthopaedics perspective. Injury. 2010. 41. (2): 161-168.

31. Sala F., Elbatrawy Y., Thabet A. M., Zayed M., Capitani D.: Taylor spatial frame fixation in patients with multiple traumatic injuries: study of 57 long-bone fractures. J. Orthop. Trauma. 2013. 27. (8): 442-450. 
32. Sala F., Thabet A. M., Castelli F., Miller A. N., Capitani D., Lovisetti G., Talamonti T., Singh S.: Bone transport for postinfectious segmental tibial bone defects with a combined Ilizarov/Taylor spatial frame technique. J. Orthop. Trauma. 2011. 25. (3): 162-168.

33. Sharma H., Nunn T.: Conversion of open tibial IIIb to IIla fractures using intentional temporary deformation and the Taylor Spatial Frame. Strategies Trauma Limb Reconstr. 2013. 8. (2): 133-140.

34. Shenoy R., Kubicek G., Pearse M.: The Taylor Spatial Frame ${ }^{T M}$ for correction of neglected fracture dislocation of the ankle. J. Foot Ankle Surg. 2011. 50. (6): 736-739.

35. Shisha T., Kiss S., Pap K., Berki S., Antal I., Szőke Gy.: Az izom-ín komplexek tömegének változása a tibia elongatio során. Magyar Traumatológia Ortopédia Kézsebészet Plasztikai Sebészet, 2008. 51: 139-144.

36. Shisha T., Kiss S., Pap K., Simpson H., Szöke Gy.: Relative ability of young and adult muscle to respond to limb lengthening. J. Bone Joint Surg. 2006. 88-B: 1666-1669.

37. Simpson A. L., Ma B., Slagel B., Borschneck D. P., Ellis R. E.: Computer-assisted distractian osteogernes.s by lizcurov's method. Int. J. Med. Robot. 2008. 4. (4): 310-320.

38. Sluga M., Pfeiffer M., Kotz R., Nehrer S.: Lower limb deformities in children: two-stage correction using the Taylor spatial frame. J. Pediatr. Orthop. B. 2003. 12. (2): 123-128.

39. Stevens P. M.: Guided growth for angular correction: a preliminary series using a tension band plate. J. Pediatr. Orthop. 2007. 27. (3): 253-259.

40. Tafazal S., Madan S. S., Ali F., Padman M., Swift S., Jones S., Fernandes J. A.: Management of paediatric tibial fractures using two types of circular external fixator: Taylor spatial frame and llizarov circular fixator. J. Child Orthop. 2014. 8. (3): 273-279.

41. Tetsworth K. D., Paley D.: Accuracy of correction of complex lower extremity deformities by the llizarov method. Clin. Orthop. 1994. 301: 102-110.

42. Watanabe K., Tsuchiya H., Sakurakichi K., Matsubara H., Tomita K.: Double-level correction with the Taylor Spatial Frame for shepherd's crook deformity in fibrous dysplasia. J. Orthop. Sci. 2007. 12. (4): 390-394.

43. www.jcharlestaylor.com

44. Vízkelety T., Kiss S.: A végtaghosszabbitás lehetöségei. Lege Artis Medicinae, 2003. 13: 649-654.

45. Zenios M., Oyadiji S. O.: Effect of asymmetrical configuration of pins in the TSF external fixator used for tibial lengthening in a pediatric population. J. Pediatr. Orthop. 2014. 34. (6): 618-624.

\section{Dr. Domos Gyula}

SE Ortopédiai Klinika

1113 Budapest, Karolina út 27. 